\title{
Well-being at work and its association with work-home interactions: a study of young Vietnamese employees
}

\section{BACKGROUND}

Studying well-being at work and how it is related to employees' work-home interactions has been of great concern to both researchers and policy-makers in recent years. The aim of this study is to investigate the status of well-being at work of young Vietnamese employees working in Hanoi city and how dimensions of their work-home interaction contribute to their well-being at work.

\section{PARTICIPANTS AND PROCEDURE}

A self-administered questionnaire survey was conducted on 675 Vietnamese employees whose age was under 35 years. Demo and Paschoal's well-being at work scale and the Survey Work-Home Interaction - Nijmegen (SWING) scale were applied to measure employees' well-being at work and work-home interactions respectively. The control variables include employees' sex, marital status, working tenure, work position, mentoring, and type of organization.

\section{RESULTS}

This study documented differences in the status of wellbeing at work between groups by gender, work position, mentoring, whereas no difference was found between groups in age, marital status, working tenure or types of organization. Regression results demonstrated that altogether positive work-home, negative work-home, positive home-work interactions and work position can explain quite well the variance of employees' well-being at work, and the predictive power of positive interaction for wellbeing at work was significantly stronger than that of work position and negative work-home interaction.

\section{CONCLUSIONS}

Our results suggested that to promote employees' wellbeing at work, organizations should invest in boosting the positive interactions between work and home life of employees. Work position, gender issue and mentoring are also meaningful determinants of well-being at work.

\section{KEY WORDS}

workplace well-being; positive work-home interaction; positive home-work interactions; young employees; Vietnam

ORGANIZATION - 1: Faculty of Psychology, VNU University of Social Sciences and Humanities, Vietnam National University, Hanoi, Vietnam · 2: Faculty of Sociology, VNU University of Social Sciences and Humanities, Vietnam National University, Hanoi, Vietnam

AUthors' Contributions - A: Study design - B: Data collection - C: Statistical analysis - D: Data interpretation . E: Manuscript preparation · F: Literature search · G: Funds collection

CORRESPONDING AUTHOR - Prof. Bui Thi Hong Thai, Faculty of Psychology, VNU University of Social Sciences and Humanities, Vietnam National University, 336 Nguyen Trai Str., Thanh Xuan, Hanoi, Vietnam, e-mail: hongthaibui.psy@gmail.com

to CITE this ARTICLE - Bui, T. H. T., Nguyen, T. N. T., \& Tran, T. M. D. (2021). Well-being at work and its association with work-home interactions: a study of young Vietnamese employees. Health Psychology Report, 9(1), 18-30. https://doi.org/10.5114/hpr.2020.97915

RECEIVED 16.05.2020 • REVIEWED 03.06.2020 • ACCEPTED 16.06.2020 • PUBLISHED 06.08.2020 


\section{BACKGROUND}

What is the status of well-being at work and how is it related to the interactions between work and home affairs among Vietnamese employees? This is a crucial question for not only organization managers but also for policy-makers, especially in this transition period when Vietnam is experiencing a very fast pace of economic development and social changes. It has been acknowledged that the balance between work and home domains imposes a remarkable effect on employee well-being (Gervais et al., 2013). In turn, employees' well-being at work plays vital role in determining the productivity, stability and development of the organization in particular and the economy in general (Di Fabio, 2017; Haddon, 2018). However, the interactions between work and home life become more and more challenging in workforces due to modern issues such as the growing number of dual-earner couples or single parents in a variety of contexts. Dikkers et al. (2007), when reviewing research on this topic, stated that $40 \%$ of employed parents in the US experienced interference between work and home life, and this rate was even higher among Dutch and Canadian employees. Geurts et al. (2005, p. 333) further pointed out that the negative impact appears to originate more often from work than from the home domain, since "work boundaries were less flexible than home boundaries due the forced structure and obligatory nature of paid work".

In Vietnam, the question of how work-home interaction affects employees' well-being at work is of great importance. Beside practical implications that studying employees' well-being at work and its association with work-home interactions may bring about to both organizational and societal management, investigation of these issues in the context of an Asian economy like Vietnam where it is experiencing a transition from a central-command to marketbased, from agricultural to industrial economy may contribute more understanding of this association and the broader interactions between social factors (such as economics, culture, or law) and individual issues (such as value orientations, family, or career).

Unfortunately, little is known about the association between work-home interactions and Vietnamese employees' well-being at work. Psychological studies on Vietnamese employees have been conducted since 2000s with a focus on their work motivation and job satisfaction and how these issues were related to social demographic and organizational factors (Nguyen, 2012). Regarding the interaction between work and home, most of the existing studies on Vietnamese employees concentrated on examining how family affects achievements in work especially among female employees (Le, 2015), instead of considering the mutual effects between work and home.
This study is one of the first efforts to explore the association between work-home interaction and the well-being at work of Vietnamese employees. In line with previous studies on this topic and considering specific conditions of the Vietnamese context, this study examines this association with regard to some individual-family factors such as gender, age, marital status, number of children; work tenure; and organizational factors such as mentoring (i.e. whether organizations provide supportive resources to employees); and types of organizations (public vs. nonpublic organizations). Advised by previous studies (e.g. Guest, 2002; Kossek et al., 2011; Sok et al., 2014) that balancing work and home life is increasingly difficult for high-skilled employees, this study was conducted on young Vietnamese and highly educated employees who have completed higher education programs.

\section{KEY CONCEPTS AND LITERATURE REVIEW}

\section{WELL-BEING AT WORK}

Well-being, one of the most interesting concepts in psychological studies, can be categorized into two types as suggested by Warr (1987): context-free and context-specific well-being. According to Taris and Schaufeli (2015), the difference between these two types is that context-free, or sometimes called global/ general well-being, does not focus on any particular area of life while well-being at work is considered as a result of the employee's work experiences at the workplace.

Well-being at work has been conceptualized in various ways and it seems difficult to establish a uniform definition. The literature of employee's wellbeing demonstrates that it can be understood and evaluated by various indicators which fall into one of the opposite sides at work that employees can experience: satisfaction vs. dissatisfaction, pleasure vs. displeasure, psychological and physical wellness vs. illness, investment vs. divestment, etc. In a broader overview, the conceptualization of well-being at work traditionally follows two approaches: hedonism and eudaimonism. The former refers to the affective state of well-being and maintains that positive emotion and pleasure in general are the ultimate goal of life (Diener et al., 1999). In this perspective, individual well-being can be examined by indicators reflecting positive vs. negative affect, happiness and life satisfaction. Meanwhile, the latter approach focuses on the actualization of human potentials, and in this way individual well-being is examined in six aspects: self-acceptance, positive social relation, autonomy, environmental mastery, purpose in life, and personal growth (Ryff, 1989; Ryff \& Keyes, 1995). In sum, the
The association between well-being at work and work-home interactions 
Bui Thi Hong Thai, Nguyen Thi Nhu Trang, Tran Thi Minh Duc eudaemonist approach emphasizes individual flourishing and fulfillment (Page \& Vella-Brodrick, 2009).

Accordingly, the research of well-being at work, inspired by numerous studies in general well-being (Taris \& Schaufeli, 2015), has used various indicators to evaluate it. For example, based on the hedonism approach, van Dierendonck et al. (2004) adopted two indices of well-being at work, i.e. job-related depression and anxiety symptoms and context-free related mental health issues among employee. On the other hand, Park and Searcy (2012) studied employee's well-being by simply three items reporting the degree to which the job had made the individual feel tense, worried, and uneasy in the past few weeks. In Vietnam, it seems that the question of well-being at work is not yet of interest to researchers because of the absence of studies on this subject directly. Most of the studies follow hedonism perspective by focusing on employee's job satisfaction (e.g. Tran et al., 2013), or depression symptoms at work (e.g. Tran et al., 2019). Based on the eudaimonism approach, Jonge et al. (2000) evaluated employee's well-being by job satisfaction, emotional exhaustion, physical health symptoms, and psychosomatic health complaints, regarding job strain and effort-reward imbalance; and by job satisfaction, emotional exhaustion, and work motivation in another study (Jonge et al., 2001); Bond and Donaldso-Feilder (2004) studied employee's well-being by job satisfaction, physical wellbeing and general mental health; while Schaufeli et al. (2008) carried out a study in an effort to examine whether workaholism, burnout, and work engagement are three different kinds of employee's well-being, or three of a kind. The authors confirmed the multifaceted nature of well-being at work.

However, some researchers have recently claimed that these two approaches are not enough to understand well-being at work (Delle Fave et al., 2011), based on the fact that most people experience high level of well-being in either the hedonist or eudaimonist aspect, but not both (Keyes et al., 2002). Thus, it is possible that insisting on a single perspective when studying well-being at work can only demonstrate either the employee's level of happiness or describe his/her meaning and self-achievement at work. While in regard to the job-specific domain, pleasure experience was found to be an essential element in judging well-being at work (Paschoal et al., 2010), in addition, employee's fulfillment and flourishing were also seen as important factors of well-being at work (Taris \& Schaufeli, 2015).

In this study, we adopted the perspective that wellbeing at work, as suggested by previous studies (Delle Fave et al., 2011; Demo \& Paschoal, 2016), should be examined by combining hedonist and eudaimonist aspects. It is because this study was conducted on young employees with a high academic level, who often have a strong need to perform their skills and express their values at work in order to meet complicated job expectations and demands in the context of labor market changes (Tomlinson, 2012), especially for young Vietnamese graduate employees in the context of socio-economic transition which provides them many new challenges in their professional integration. Personal values at work, such as fulfilling personal potential or expressing one's self-efficacy at work, which were not respected in the centrally planned and subsidized economy in Vietnam before the Economic Renovation, have now become more and more important in the workplace, especially among intellectual employees. Thus, to obtain wellbeing at work employees must at the same time experience positive affect and have a sense of fulfillment at work. Therefore, it seems suitable to apply a combination of hedonist and eudaimonist perspectives in examining well-being at work in this study.

\section{WORK-HOME INTERACTIONS}

Several studies have acknowledged the significant relationship between well-being at work and workhome interactions. Compared to well-being at work, work-home interactions have stepped on the stage more lately but have quickly become a matter of great concern among researchers, organization managers, and policy makers in Western societies (Sok et al., 2014). As to the concept of well-being at work, there is no uniform conceptualization of work-home interaction. The mutual effects between the work and the home domain have been studied under various conceptual umbrellas and can generally be categorized into two points of view: individual focus and organizational focus. When being seen as an individual issue, the mutual interaction between work and home life has been examined as work-family conflict (e.g. Judge et al., 2006), work-home interference (Verweij et al., 2017), work-home interactions (Geurts et al., 2005), or an individual's strategies to reconcile work and private life. In the broader approach, this issue, often called work-home culture, has been examined as organizational strategies to improve the supportive association between work and home life of employees.

Despite the differences, the key idea underlying these concepts is, as explained by Van Aarde and Mostert (2008), that "work" and "home" were not separate domains; instead, they are highly interrelated. As written by Van Aarde and Mostert (2008, p. 2), "work can be defined as a set of (prescribed) tasks that an individual performs while occupying a position in an organization. Home (or non-work) may refer to activities and responsibilities within the family domain, as well as to activities and obligations beyond one's own family situation. It also involves activities (within and beyond the family domain) that cannot 
simply be considered leisure or spare time, because they involve (similar to the work domain) obligations and responsibilities (e.g. household activities, caregiving responsibilities and social obligation)".

There are different ways to conceptualize and measure the interaction between work and home life of employees. In this study we applied the Survey Work-Home Interaction - Nijmegen (SWING) scale (Geurts et al., 2005) because it represents quite a comprehensive approach and has been popularly applied in various contexts (Rost \& Mostert, 2007). This scale was developed as an effort to combine the two prominent theoretical approaches explaining how work and home interact with each other. The first one, the role scarcity hypothesis, holds that playing multiple roles in the condition that resources such as time or energy are limited creates inter-role conflicts over such limited resources, which in turn results in pressure on individuals. On the other hand, the role enhancement hypothesis proposes that playing work- and home-related roles supports each other by producing resources such as energy mobilization and skills acquisition, hence facilitating the individual's functioning in both domains. Whereas empirical evidence mostly demonstrates the negative effects and rarely reveals the positive effects of work and home on each other, Geurts et al. (2005) believe that the interactions between these two crucial life spheres contain both positive and negative impacts, and define work-home interaction as an interactive process in which a worker's functioning in one domain (e.g. home) is influenced by (negative or positive) load reactions that have built up in the other domain (e.g. work).

Accordingly, Geurts and colleagues (2005) developed a measure of work-home interaction which represents two dimensions, the direction of the effect (i.e. impact of work on private life and vice versa), and the quality of the effect (i.e. negative and positive impacts). Hence, there are four interactions measured by the SWING scale: negative impact of work on home (negative WHI), positive impact of work on home (positive WHI); negative impact of home on work (negative HWI) and positive impact of home on work (positive HWI).

Many studies on the associations between workhome interactions and well-being at work find that positive interactions increase employees' well-being at work in general (Garrosa-Hernández et al., 2013), supporting the role enhancement hypothesis. At the same time, research on the relationship between negative work-home interactions (sometimes called work-home interference) documents that negative work-home interactions result in a low level of well-being in many ways, supporting the role scarcity hypothesis. Dikkers et al. (2007), reviewing several studies on this topic, documented that negative work-home interactions relate to greater psychological distress, anxiety disorders, mood disorders, lower life satisfaction, lower job satisfaction and also lower family satisfaction.

In accordance with the findings of previous studies, we hypothesize that positive work-home interactions are positively, whereas negative work-home interactions are negatively, related to young Vietnamese employees' well-being at work.

\section{CONTROL VARIABLES}

Even though existing literature on well-being at work has popularly focused on individual attributes, recent years have seen a call for an approach that incorporates both individual traits and socio-political and organizational factors of well-being at work (Ravenswood, 2017). In response, we included in our analysis some personal (gender, age, work position, work tenure, and marital status) and organizational factors (mentoring, types of organizations) which have been observed as strongly related to employees' well-being.

Gender is found to be significantly related to employee's well-being at work in many studies. It is observed that gender is associated with psychological distress, depression, anxiety and other psychosomatic illnesses (Burke, 2002; Middleton et al., 2001; Rivera-Torres et al., 2013); job satisfaction (Kim, 2005; Miao et al., 2017); or work engagement (Banihani \& Syed, 2020). It is further documented in previous studies that female employees often experience a lower level of well-being at work than their male counterparts. Beside gender, age is also a determinant of well-being at work in that older age is related to a lower level of well-being and a higher level of work stress and exhaustion (Hsu, 2018). However, higher job tenure is found to be a predictor of a higher level of job satisfaction (Bedeian et al., 1992; Lerato \& Oladele, 2011). Married working women face more multifaceted stress at the workplace than their single counterparts (Garima \& Kiran, 2014), and individuals occupy a higher job position and experience less job stress (Kawada \& Otsuka, 2011).

Regarding organizational factors, it is documented in various studies that having a mentor at the workplace, which represents a resource the organization provides to employees, increased employees' wellbeing at work (Van Aarde \& Mostert, 2008); therefore we selected mentoring to be one of the control variables. Additionally, type of organizations (public vs. non-public) was selected due to the specific politicaleconomic conditions in Vietnam. Since the Economic Renovation in 1986, various economic sectors have boomed in Vietnam; however, within the scope of this study, we only examine whether or not there is any difference in well-being at work among employees working in public vs. non-public sectors, given that employment in the public sector has been more favored among Vietnamese employees and their family
The association between well-being at work and work-home interactions 
thanks to the attached social benefits and its stability, whereas in recent years employment in the non-public sector has become more and more promising to young employees because it provides more flexibility and opportunities (World Bank, 2018). Comparison between these two sectors may produce findings beyond comparing two working environments, because it implies comparing between traditional and new (imported) values regarding job and career.

Bui Thi Hong Thai, Nguyen Thi Nhu Trang, Tran Thi Minh Duc

\section{PARTICIPANTS}

A total of 700 employees received the questionnaire, of whom 675 returned the complete survey, making a response rate of $96.4 \%$. The majority of participants were female $(67.6 \%)$. Their average age was 25.66 \pm 2.55 . A majority of them had obtained a BA degree $(85.6 \%)$ or an MA degree (14.4\%). Two thirds of them were married. About $33 \%$ of the sample had a permanent job, and $67 \%$ had a fixed term contract. Their work tenure was less than 1 year $(54.6 \%), 1$ year to 2 years $(20.2 \%)$ and 2 years to 5 years $(25.2 \%)$. At the time of the study, participants were working in different work sectors: public $(22.2 \%)$, private $(67.3 \%)$ and semi-public (10.5\%). About $10 \%$ of survey participants were managers.

\section{MEASURES}

Well-being at work. Following the integrated approach of hedonic and eudemonic, employee's wellbeing at work in this study was measured by the Wellbeing at Work Scale (WBWS), first developed and validated in Brazil by Paschoal and Tamayo (2008) and then in the USA by Demo and Paschoal (2016). Research on Brazilian employees adopted the scale with 30 items ( 9 items for positive affect, 12 items for negative affect and 9 items for fulfillment). Conducted on American employees, the results of factor analysis eliminated 1 item of fulfillment. In this study, the results of exploratory factor analysis confirmed 3 factors with 27 items (3 items were eliminated), which explained $56.74 \%$ of the variance $(\mathrm{KMO}=.94$, $p<.001$ ), including: (1) Negative affect (11 items, e.g., "My work made me feel nervous"), (2) Positive affect (8 items, e.g., "My work made me feel happy"), and (3) Personal fulfillment (8 items, e.g., "In my work, I overcome challenges"). The scale reflected excellent reliability with Cronbach's $\alpha$ of .91 . The reliability was also good for each subscale: Negative affect with $\alpha=.72$, Positive affect with $\alpha=.81$ and Fulfillment with $\alpha=.80$ (Nunnally \& Bernstein, 2006). To calculate the total score, all items in the Negative affect subscale were reversely scored, and then all the items were summed. A higher score indicates greater wellbeing at work.

Work-home interactions. The relationship between life work and life outside work was measured by the Survey Work-Home Interaction - Nijmegen (SWING) developed by Geurts et al. (2005). The scale consisted of 22 items. Exploratory factor analysis $(\mathrm{KMO}=.87$, $p<.001$ ) proposed four types of work-home interaction as proposed by authors, explaining $61.39 \%$ of the variance, including: (1) Negative work-home interaction (8 items, e.g., "I do not have the energy to engage in leisure activities with my spouse/family/friends because of my job”), (2) Negative home-work interaction (4 items, e.g., "I have difficulty concentrating on my work because I am preoccupied with domestic matters"), (3) Positive work-home interaction (5 items, e.g., "I fulfill my domestic obligations better because of the things I have learned on my job") and (4) Positive home-work interaction (5 items, e.g., "I take my responsibilities at work more seriously because I am required to do the same at home"). All items were on a 4-point Likert scale, ranging from 1 (never) to 4 (always). Cronbach's $\alpha$ coefficients of each factor were $.87, .81, .79$, and .80 for Negative work-home, Negative home-work, Positive workhome, and Positive home-work, respectively.

Well-being at work and work-home interaction scales were in the English version. The repeated forward-backward translation procedure was adopted in this study as advised by Van de Vijver and Hambleton (1996). Scales were firstly translated into Vietnamese. Then, the Vietnamese versions were translated back into English, and compared with the original English versions. Some modifications for the Vietnamese versions were made to make the wording more appropriate in Vietnamese culture expression. After that, a pilot study was conducted on 60 employees to check the face validity and reliability of the translated scales.

\section{PROCEDURE}

This is a self-report questionnaire survey. The research team contacted young employees who met the recruitment criteria (under 35 years old, highly educated) working at different organizations in Hanoi city to invite them to participate in the research and provide them information about the research, and the responsibility and rights of survey participants. Invited employees were given one week to consider the invitation and related information, then the research team contacted them again. Those who agreed to participate in the survey received a paperand-pencil questionnaire. All member of the research team were trained to ensure that the rights of participants, especially the right to self-determination and confidentiality, were respected when the research was conducted. 


\section{STATISTICAL ANALYSES}

SPSS Statistics (version 23.0) was used for all analyses. To determine how well-being at work is related to personal and organizational factors, a series of between-group analyses were completed with independent-samples $t$-tests for dichotomous variables and one-way analysis of variance for other variables. To examine the relationship between work-home interactions and employee's well-being at work, Pearson's correlation coefficients were firstly calculated, then, stepwise multiple regression analyses were conducted with the four types of work-home interactions as independent variables, personal and organizational variables that had statistically significant associations with well-being at work as control variables, and well-being at work as dependent variable. Deviation from linearity and multi-collinearity was examined in variables used in regression analyses.

\section{RESULTS}

\section{WELL-BEING AT WORK OF YOUNG VIETNAMESE EMPLOYEES}

To understand the well-being at work (WBW) of young Vietnamese employees, we examined their well-being at work in association with some personal factors including age, gender, marital status, working tenure, and work position (whether they were holding a managerial position or not at the time of questionnaire administration); and organizational factors including mentoring (whether the organization provides employees a mentor at the workplace or not), and the types of organization (public vs. non-public) where they were working.

Data revealed differences in the status of wellbeing at work between groups by sex, work position, mentoring, whereas no difference was found between groups by age, marital status, working tenure and types of organization. Work position was found related to well-being at work whereas working in a public or non-public organization was found unrelated to employees' well-being.

Table 1 presents the specific associations between the related personal and organizational factors with the three aspects of well-being at work.

When analyzing the associations between related personal and organizational factors with specific aspects of WBW as shown in Table 1, our results documented that negative affect was not related to any factor, fulfillment was related to only work position, and positive affect was related to gender, work position and mentoring. Data showed that men reported a slightly higher level of well-being at work and of positive affect than women. Meanwhile, those who were holding a managerial position reported higher levels of WBW, positive affect and fulfillment than those who were not holding a managerial position in their organization. Those who had a mentor at the workplace also reported higher levels of WBW and positive affect than those who did not. These findings confirm our hypotheses and correspond to findings of previous studies in other contexts as reviewed.

\section{Table 1}

Differences in the well-being at work of employees by gender, work position and mentoring

\begin{tabular}{|c|c|c|c|c|}
\hline & Positive affect & Negative affect & Fulfilment & Total well-being \\
\hline Gender & & & - & \\
\hline Men & $2.44(0.41)$ & & & $2.79(0.45)$ \\
\hline Women & $2.36(0.45)$ & & & $2.70(0.50)$ \\
\hline$t$-value & $t(673)=-2.11^{*}$ & $\mathrm{~ns}$ & ns & $t(673)=-2.70^{*}$ \\
\hline \multicolumn{5}{|l|}{ Work position } \\
\hline Managerial & $2.47(0.41)$ & & $3.06(0.45)$ & $2.97(0.42)$ \\
\hline Non-managerial & $2.37(0.44)$ & & $2.84(0.40)$ & $2.70(0.48)$ \\
\hline$t$-value & $t(671)=1.83^{*}$ & ns & $t(671)=4.35^{* *}$ & $t(671)=4.44^{* *}$ \\
\hline \multicolumn{5}{|l|}{ Mentoring at work } \\
\hline Yes & $2.42(0.43)$ & & & $2.77(0.48)$ \\
\hline No & $2.31(0.41)$ & & & $2.65(0.49)$ \\
\hline$t$-value & $t(672)=3.14^{* *}$ & $\mathrm{~ns}$ & ns & $t(672)=3.01^{* *}$ \\
\hline
\end{tabular}

Note. ${ }^{*} p<.05,{ }^{* *} p<.01$, standard deviation is in parentheses, ns - non-significant. 
Bui Thi Hong Thai, Nguyen Thi Nhu Trang, Tran Thi Minh Duc

\section{ASSOCIATION BETWEEN WORK-HOME INTERACTIONS AND WELL-BEING AT WORK}

As shown in Table 2, well-being at work was found to be positively related to positive work-home and home-work interactions, and negatively related to negative home-work interaction. The strengths of the relationships between well-being at work with positive interactions were found remarkably stronger in comparison to its relationship with negative interaction between home and work life. However, it was found in this study that WBW was not related to negative work-home interaction. Therefore, we discarded negative WHI when running multiple regression to examine how dimensions of work-home interactions relate to employees' well-being at work.

The three aspects of work-home interaction and the related personal and organizational factors including gender, work position and mentoring were input into a multiple regression analysis using the stepwise method. By this method, gender and mentoring at work were removed from the model. The results of multiple regression analysis are presented in Table 3.

The results showed that positive WHI, negative WHI and positive HWI and work position altogether explained $38.9 \%$ of the variance of employees' wellbeing at work. The predictive power of positive work-home $(\beta=.42)$ and positive home-work interaction $(\beta=.41)$ for well-being at work is significantly stronger than that of negative work-home interaction $(\beta=-.16)$ and work position $(\beta=.11)$.

\section{DISCUSSION}

In line with previous studies, this study found that the well-being at work of young Vietnamese employees was related to some personal and organizational

Table 2

Zero-order relations between well-being at work and work-home interactions $(N=675)$

\begin{tabular}{|c|c|c|c|c|c|c|c|c|c|c|}
\hline & $M$ & $S D$ & 1 & 2 & 3 & 4 & 5 & 6 & 7 & 8 \\
\hline 1. PA & 2.39 & 0.44 & - & & & & & & & \\
\hline 2. NA & 1.97 & 0.59 & $-.16^{* * *}$ & - & & & & & & \\
\hline 3. Fulfilment & 2.63 & 0.63 & $.76^{* * *}$ & $-.12^{* * *}$ & - & & & & & \\
\hline 4. Total WBW & 2.73 & 0.49 & $.65^{* * *}$ & $-.29^{* * *}$ & $.69^{* * *}$ & - & & & & \\
\hline 5. NWHI & 1.97 & 0.49 & $-.27^{* * *}$ & $.40^{* * *}$ & $.08^{*}$ & ns & - & & & \\
\hline 6. PWHI & 2.53 & 0.50 & ns & $-.10^{*}$ & $.32^{* * *}$ & $.43^{* * *}$ & ns & - & & \\
\hline 7. NHWI & 1.97 & 0.43 & ns & $.43^{* * *}$ & ns & $-.16^{* * *}$ & $.54^{* * *}$ & ns & - & \\
\hline 8. PHWI & 2.68 & 0.40 & $.29^{* * *}$ & $-.10^{* *}$ & $.28^{* * *}$ & $.42^{* * *}$ & ns & $.65^{* * *}$ & ns & - \\
\hline
\end{tabular}

Note. PA - positive affect, NA - negative affect, WBW - well-being at work, NWHI - negative work-home interactions, PWHI positive work-home interactions, NHWI - negative home-work interactions, PHWI - positive home-work interactions; ns - nonsignificant; ${ }^{*} p<.05,{ }^{* *} p<.01,{ }^{* * *} p<.001$.

Table 3

Results from stepwise regression analysis for well-being at work

\begin{tabular}{|c|c|c|c|c|c|c|}
\hline & \multicolumn{2}{|c|}{$\begin{array}{l}\text { Unstandardized } \\
\text { coefficients }\end{array}$} & \multirow{2}{*}{$\begin{array}{c}\text { Standardized } \\
\text { coefficients }\end{array}$} & \multirow[t]{2}{*}{$t$} & \multirow[t]{2}{*}{$F$} & \multirow[t]{2}{*}{$R^{2}$ adjusted } \\
\hline & $B$ & $S E$ & & & & \\
\hline Constant & .71 & .14 & & $5.03^{* * *}$ & $107.96^{* * *}$ & .39 \\
\hline PWHI & .41 & .03 & .42 & $13.94^{* * *}$ & & \\
\hline PHWI & .49 & .04 & .41 & 13.50 *** & & \\
\hline NHWI & -.18 & .03 & -.16 & $-5.16^{* * *}$ & & \\
\hline Work position $^{\mathrm{a}}$ & .17 & .05 & .11 & $3.54^{* * *}$ & & \\
\hline
\end{tabular}

Note. PWHI - positive work-home interactions, PHWI - positive home-work interactions, NHWI - negative home-work interactions; ${ }^{a}$ work position: 0 - non-managerial, 1 - managerial; ${ }^{* * *} p<.001$. 
factors such as gender, work position, and mentoring at work. To be more specific, holding a managerial position in the workplace is associated with a higher level of general well-being at work, and specifically with positive affect in work and the feeling of fulfilment. This result corresponds to previous studies showing that persons who have higher job status tend to report a higher level of workplace wellbeing in terms of feeling of achievement (Praveen, 2018), self-accomplishment (Creed et al., 2009), or job satisfaction (Stalcup \& Pearson, 2001). Brief and Aldag (1975) explain this association by suggesting that higher status at the workplace provides greater autonomy and independence in the job, more challenges, responsibilities, variety, and task identity, and hence better satisfies the individual's psychological needs in the career. In addition, higher salary and more rewards (Park \& Gursoy, 2012), more workrelated opportunities and benefits (Hansen \& Høst, 2012) also contribute to higher workplace well-being scores among managers. Especially in a society like Vietnam where hierarchy is important and those higher up in the system are highly respected, holding a managerial position will strongly boost employees' sense of self-accomplishment and competence, hence increasing their feeling of fulfillment and satisfaction in work.

Having a mentor at the workplace also significantly relates to well-being at work and employees' sense of positive affect in work, which is in line with previous studies as reviewed by Garvey and GarrettHarris (2008). More recently, the work of Kutsyuruba et al. (2019) also recognizes the positive correlation between mentorship and well-being at work. In practice, mentoring has been considered as a crucial component of programs supporting new employees thanks to its contribution to employees' effectiveness, self-confidence, self-efficacy, or stress reduction (Fenwick, 2011; Henry et al., 2011) by guiding, leading, advising, even counselling, and developing interpersonal relationships (Harrison et al., 2005). This study, hence, lends support to the organizational strategy of providing mentoring to new recruits to promote their well-being at work as suggested by Hobson and Maxwell (2016). However, this study recognizes that negative affect and fulfillment are not related to mentoring. Unfortunately, our data are not enough to explain this finding. We hope that future studies, especially those with an ethnographical approach, may provide more insight into the relationship between components of wellbeing at work and mentoring at work, or discover what factor neutralizes the relationship between negative affect and fulfillment with mentoring at work.

Interestingly, age, working tenure, marital status, and type of organizations were found unrelated to well-being at work. These results are, interestingly, opposed to our expectation that in a culture where older age is highly respected, like Vietnam, those who are older and experiencing longer working tenure might experience a higher level of well-being at work than the others. Even though the fact that no relation between age and working tenure with well-being at work was found may be partly because this study targeted young (under 35 years old) and highly educated (completed a BA program or higher) persons, this result may also signal a change in the current Vietnamese workforce which increasingly favors new values such as productivity and effectiveness to traditional values such as experience and qualifications.

Similarly, working in the public or non-public sector was found unrelated to employees' well-being, which is contrary to our expectation that, because the Vietnamese traditionally prefer working in the public sector since employment in the public sector is associated with social benefits and is much more stable than in the non-public sector (World Bank, 2018), the employees of the public sector would experience a higher level of well-being at work than their counterparts in the non-public sector. The fact that this study documents no difference in wellbeing at work among employees working for public and nonpublic organizations suggests that young Vietnamese employees have in general worked for the type of organization suitable for their career orientation. This finding also implies that the new generation of Vietnamese employees have their voice in deciding their job and the type of organization they work at, and signals a decrease in family's traditionally decisive impact on youth's career orientation. Once youths' career expectations are taken into account so that most young employees are working for the type of organization suitable for them, then type of organization is not a factor that contributes to the difference in wellbeing at work among young employees. More interestingly, marital status was also found not related to well-being at work of employees. These findings however lend support to our core proposition that having a family or not, and working in a stable environment like the public sector or, on the other hand, an environment that is challenging but more open to new opportunities like the non-public sectors does not matter. It is how work and home life interact with each other that matters to employees' well-being at work.

In regard to gender, it was found in this study that being a man or woman does not make any difference in the level of negative affect in work nor sense of fulfillment among young Vietnamese employees. However, gender is found associated with well-being in general and positive affect in particular. To be more specific, male employees tend to experience a higher level of well-being and positive affect at the workplace than females do. The difference in well-being at work between genders among Vietnamese employ-
The association between well-being at work and work-home interactions 
Bui Thi Hong Thai, Nguyen Thi Nhu Trang, Tran Thi Minh Duc ees is consistent with the findings of many studies in other contexts (Achour et al., 2017; Wilks \& Neto, 2013), showing that this gender difference in well-being at work is a social construction rather than a result of biological traits. This finding further suggests that domestic responsibilities assigned to women have not been changed much (Aguiar \& Hurst, 2007) whereas their participation in the labor market has remarkably increased - especially in Vietnam, where society constantly praises and expects women's dual responsibility as expressed in a famous slogan assigning that Vietnamese women are "capable of national affairs and duteous at housework" (giỏi việc nước, đảm việc nhà). This multiple role may explain the lower level of positive affect in work and wellbeing at work in general among Vietnamese female employees in comparison to their male counterparts.

There are some notable findings of this study on young Vietnamese employees with regard to work home interactions. Firstly, the mean scores of positive work-home and positive home-work interactions are higher than mean scores of negative work-home and negative home-work interactions among young employees. This is consistent with Grzywacz and Marks (2000)'s finding that employees with a low level of education experience a lower level of positive spillover from work to home. In the same line, Oldfield and Mostert (2011) reported that employees with a higher level of education experience a low level of negative work-home/home-work balance. This finding suggests that, on average, participants of the current study are able to maintain the balance and boost the mutual support between work and home domains. Secondly, positive interactions between home and work life, regardless of which direction this interaction is in, significantly related to well-being at work and the strengths of these relations appear quite high, even in a multiple regression analysis when the effects of related personal and organizational factors are taken into account. Meanwhile, among the two types of negative interactions between home and work life, only a negative impact of home on work affects the well-being at work of employees, and the strength of the relationship between negative work-home interactions with well-being at work is considerably smaller than the strengths of the relation between positive interactions and well-being at work. Previous studies also documented the positive correlation between positive interactions between work and home life and employees' well-being at work, while a negative correlation between negative home-work interaction and well-being, and no correlation between negative work-home and well-being was observed (Laba \& Geldenhuys, 2018; Rothmann \& Baumann, 2014). Our study hence lends support to the role enhancement hypothesis which posits that the role fulfilment in a certain life domain may produce resources facilitating the functioning in another life domain.
Interestingly, our study finds that all the related personal and organizational factors (gender, mentoring and work position) are significantly related to positive affect in work whereas none of them has an association with employees' negative affect in work. What makes positivity so special to Vietnamese employees? This interesting question is unfortunately beyond the scope of this current study; however, this study suggests that more investigation on positive vs. negative aspects of both well-being at work and work-home interaction should be conducted on different populations to determine whether this power of positivity specifically affects Vietnamese employees or not. It should also be noted that previous studies have documented that both male and female employees experience positive interactions between work and home life more than negative ones (Achour et al., 2017; Laba \& Geldenhuys, 2018).

Another notable finding of this study is about the effect of gender and mentoring on well-being at work. It is expected that these factors will exert a considerable effect on well-being at work among Vietnamese employees. Gender inequality remains a great obstacle for women in Vietnam when participating in the labor force, manifested in various dimensions such as limited work opportunity, lower pay, and discrimination against their competences and ability. Hence, it is understandable that our data reveal that male employees experience a higher level of well-being at work than their female counterparts. Similarly, mentoring is expected as a powerful predictor for well-being at work (Cooper-Thomas et al., 2014) since it helps reduce uncertainty in role performance and increases social integration in the work place, which in turn increases well-being at work (Appau et al., 2019; Parker et al., 1997), and the association between mentoring and well-being at work was also statistically significant in simple regression analysis. However, both gender and mentoring were removed from the multiple regression analysis using the stepwise method. This suggests that the effects of gender and mentoring have been metabolized into the effect of work-home interaction and/or work position on well-being at work. This study suggests that further research, especially longitudinal research, should be conducted to investigate the latent associations between gender, mentoring, well-being at work, work position and work-home interactions among employees.

\section{CONCLUSIONS}

Our findings posit that well-being at work is determined largely by gender and organization-related factors as work position, mentoring at work and the interactions between work and home life. Our findings also support the perspective that well-being at 
work should not be treated as a single construct; instead, it should be examined as a multifaceted concept since its components - positive affect, negative affect, and fulfillment - are related to personal and organizational factors in different manner.

In line with other studies (e.g. Greenhaus \& Kossek, 2014), this study holds that work and home experiences are inextricably intertwined and the interactions between work and home domain are related to employees' well-being in a complicated way, and hence lend support to the Geurts et al. (2005) conceptualization of work-home interaction in four dimensions.

Our results also document a stronger impact of positive interactions between work and home life on employees' well-being in comparison with the impact of negative interactions. These results, hence, provide some support to the hypothesis that employees' over-involvement in one role does make up for the deficiencies in another role through a compensation mechanism as suggested by Rothbard (2001). However, this over-involvement in a life domain is unable to compensate the negative emotion produced in another life domain, as also found in some previous studies (Babic et al., 2017; Lundberg \& Schaufeli, 2006).

Our findings also support the perspective that organizations should invest in strategies that promote the mutual support between work and private life of employees. Among these strategies, our findings suggest that strategies that focus on boosting positive interactions between work and private life of employees may be more efficient to young and highly educated Vietnamese employees.

Last but not least, this study was conducted in a context where the work place and home are separate spaces. The coronavirus pandemic has introduced a new social structure where the home becomes a hub for both work life and home life, making work and home interactions more intensive and complicated. In addition, not only the coronavirus pandemic matters to the work-home interaction, but in the near future, with the rapid progress in technology, working from home may become the 'new normal' and hence new issues will be raised for the work-home interactions of employees. Future research may explore the nature of work-home interactions in this context and how these interactions may re-define the concept of wellbeing at work of employees.

\section{LIMITATIONS}

The study had some limitations. It used a self-report questionnaire survey to examine well-being at work and work-home interactions, which might produce some contamination of the reported relationships by means of the common-method variance. Additionally, since this is a cross-sectional study it is unable to generate any causal inference about employees' well-being and its association with work-home interactions and related personal and organizational factors. If a longitudinal study can be conducted, a better understanding of the association between well-being at work and its causes may be obtained, and hence more effective practical implications for managers and policy-makers can be produced. In addition, the sample of this study is somewhat homogeneous in that it targeted young and highly educated employees. Future research may be expanded to different samples such as middle-aged employees or employees working in the informal sector to give more insight into employees' well-being at work and its relation with work-home interactions in different situations and contexts.

\section{REFERENCES}

Achour, M., Binti Abdul Khalil, S., Binti Ahmad, B., Mohd Nor, M. R., \& Zulkifli Bin Mohd Yusoff, M. Y. (2017). Management and supervisory support as a moderator of work-family demands and women's well-being: a case study of Muslim female academicians in Malaysia. Humanomics, 33, 335356. https://doi.org/10.1108/H-02-2017-0024

Aguiar, M., \& Hurst, E. (2007). Measuring trends in leisure: The allocation of time over five decades. Quarterly Journal of Economics, 122, 969-1006. https://doi.org/10.1162/qjec.122.3.969

Appau, S., Churchill, S. A., \& Farrell, L. (2019). Social integration and subjective wellbeing. Applied Economics, 51, 1748-1761. https://doi.org/10.1080/000 36846.2018.1528340

Babic, A., Stinglhamber, F., Bertrand, F., \& Hansez, I. (2017). Work-home interface and well-being: a cross-lagged analysis. Journal of Personnel Psychology, 16, 46-55. https://doi.org/10.1027/18665888/a000172

Banihani, M., \& Syed, J. (2020). Gendered work engagement: Qualitative insights from Jordan. International Journal of Human Resource Management, 31,611-637. https://doi.org/10.1080/09585192.2017. 1355838

Bedeian, A. G., Ferris, G. R., \& Kacmar, K. M. (1992). Age, tenure, and job satisfaction: a tale of two perspectives. Journal of Vocational Behavior, 40, 33-48. https://doi.org/10.1016/0001-8791(92)90045-2

Bond, F. W., \& Donaldso-Feilder, E. J. (2004). The relative importance of psychological acceptance and emotional intelligence to workplace well-being. British Journal of Guidance \& Counselling, 32, 187203. https://doi.org/10.1080/08069880410001692210

Brief, A., \& Aldag, R. (1975). Employee reactions to job characteristics: a constructive replication. Journal of Applied Psychology, 60, 182-186. https://doi. org/10.1037/h0076548
The association between well-being at work and work-home interactions 
Bui Thi Hong Thai, Nguyen Thi Nhu Trang, Tran Thi Minh Duc
Burke, R. (2002). Work stress and women's health: Occupational status effects. Journal of Business Ethics, 37, 91-102. https://doi.org/10.1023/A: 1014734302972

Cooper-Thomas, H. D., Paterson, N. L., Stadler, M. J., \& Saks, A. M. (2014). The relative importance of proactive behaviors and outcomes for predicting newcomer learning, well-being, and work engagement. Journal of Vocational Behavior, 84, 318-331. https://doi.org/10.1016/j.jvb.2014.02.007

Creed, P., Fallon, T., \& Hood, M. (2009). The relationship between career adaptability, person and situation variables, and career concerns in young adults. Journal of Vocational Behavior, 74, 219-229. https://doi.org/10.1016/j.jvb.2008.12.004

Delle Fave, A., Brdar, I., Freire, T., Vella-Brodrick, D., \& Wissing, M. (2011). The eudaimonic and hedonic components of happiness: Qualitative and quantitative findings. Social Indicators Research, 100, 185-207. https://doi.org/10.1007/s11205-010-9632-5

Demo, G., \& Paschoal, T. (2016). Well-Being at Work Scale: Exploratory and confirmatory validation in the USA. Paidéia (Ribeirão Preto), 26, 35-43. https://doi.org/10.1590/1982-43272663201605

Di Fabio, A. (2017). Positive healthy organizations: Promoting well-being, meaningfulness, and sustainability in organizations. Frontiers in Psychology, 8, 1938. https://doi.org/10.3389/fpsyg.2017.01938

Diener, E., Suh, E., Lucas, R., \& Smith, H. (1999). Subjective well-being: Three decades of progress. Psychological Bulletin, 125, 276-302. https://doi. org/10.1037/0033-2909.125.2.276

Dikkers, J. S. E., Geurts, S. A. E., Dulk, L. D., Peper, B., Taris, T. W., \& Kompier, M. A. J. (2007). Dimensions of work-home culture and their relations with the use of work-home arrangements and work-home interaction. Work \& Stress, 21, 155-172. https:// doi.org/10.1080/02678370701442190

Fenwick, A. (2011). The first three years: Experiences of early career teachers. Teachers and Teaching, 17, 325343. https://doi.org/10.1080/13540602.2011.554707

Garima, M., \& Kiran, U. V. (2014). Impact of marital status on mental health of working women. Journal of Medical Science and Clinical Research, 2, 2594-2605.

Garrosa-Hernández, E., Carmona-Cobo, I., Ladstätter, F., Blanco, L. M., \& Cooper-Thomas, H. D. (2013). The relationships between family-work interaction, job-related exhaustion, detachment, and meaning in life: a day-level study of emotional well-being. Revista de Psicología del Trabajo y de las Organizaciones, 29, 169-177. https://doi. org/10.5093/tr2013a23

Garvey, B., \& Garrett-Harris, R. (2008). The benefits of mentoring: a literature review. The East of England Development Agency.

Gervais, R. L., Buffet, M. A., Liddle, M., \& Eeckelaert, L. (2013). Well-being at work: Creating a sup- portive work environment. European Agency for Safety and Health at Work.

Geurts, S. A. E., Taris, T. W., Kompier, M. A. J., Dikkers, J. S. E., Van Hooff, M. L. M., \& Kinnunen, U. M. (2005). Work-home interaction from a work psychological perspective: Development and validation of a new questionnaire, the SWING. Work \& Stress, 19, 319-339. https://doi.org/10.1080/02678370500410208

Greenhaus, J. H., \& Kossek, E. E. (2014). The contemporary career: a work-home perspective. Annual Review of Organizational Psychology and Organizational Behavior, 1, 361-388. https://doi.org/10.1146/ annurev-orgpsych-031413-091324

Grzywacz, J. G., \& Marks, N. F. (2000). Reconceptualizing the work-family interface: an ecological perspective on the correlates of positive and negative spillover between work and family. Journal of Occupational Health Psychology, 5, 111-126. https://doi. org/10.1037//1076-8998.5.1.111

Guest, D. (2002). Perspectives on the study of worklife balance. Social Science Information, 41, 255-279. https://doi.org/10.1177/0539018402041002005

Haddon, J. (2018). The impact of employees' well-being on performance in the workplace. Strategic $H R$ Review, 17, 72-75. https://doi.org/10.1108/SHR-012018-0009

Hansen, J. R., \& Høst, V. (2012). Understanding the relationships between decentralized organizational decision structure, job context, and job satisfaction - a survey of Danish public managers. Review of Public Personnel Administration, 32, 288-308. https://doi.org/10.1177/0734371X12449023

Harrison, J. K., Lawson, T., \& Wortley, A. (2005). Mentoring the beginning teacher: Developing professional autonomy through critical reflection on practice. Reflective Practice, 6, 419-441. https://doi. org/10.1080/14623940500220277

Henry, G. T., Bastian, K. C., \& Fortner, C. K. (2011). Stayers and leavers: Early-career teacher effectiveness and attrition. Educational Researcher, 40, 271280. https://doi.org/10.3102/0013189X11419042

Hobson, A., \& Maxwell, B. (2016). Supporting and inhibiting the well-being of early career secondary school teachers: Extending self-determination theory. British Educational Research Journal, 43, 168-191. https://doi.org/10.1002/berj.3261

Hsu, H. C. (2018). Age differences in work stress, exhaustion, well-being, and related factors from an ecological perspective. International Journal of Environmental Research and Public Health, 16, 50. https://doi.org/10.3390/ijerph16010050

Jonge, J., Bosma, H., Peter, R., \& Siegrist, J. (2000). Job strain, effort-reward imbalance and employee well-being: a large-scale cross-sectional study. Social Science \& Medicine, 50, 1317-1327. https://doi. org/10.1016/S0277-9536(99)00388-3

Jonge, J., Dormann, C., Janssen, P. P. M., Dollard, M. F., Landeweerd, J. A., \& Nijhuis, F. J. N. (2001). Testing 
reciprocal relationships between job characteristics and psychological well-being: a cross-lagged structural equation model. Journal of Occupational and Organizational Psychology, 74, 29-46. https:// doi.org/10.1348/096317901167217

Judge, T. A., Ilies, R., \& Scott, B. A. (2006). Work-family conflict and emotions: Effects at work and at home. Personnel Psychology, 59, 779-814. https:// doi.org/10.1111/j.1744-6570.2006.00054.x

Kawada, T., \& Otsuka, T. (2011). Relationship between job stress, occupational position and job satisfaction using a brief job stress questionnaire (BJSQ). Work, 40, 393-399. https://doi.org/10.3233/ wor-2011-1251

Keyes, C. L., Shmotkin, D., \& Ryff, C. D. (2002). Optimizing well-being: The empirical encounter of two traditions. Journal of Personality and Social Psychology, 82, 1007-1022. https://doi.org/10.1037/00223514.82.6.1007

Kim, S. (2005). Gender differences in the job satisfaction of public employees: a study of Seoul Metropolitan Government, Korea. Sex Roles, 52, 667-681. https://doi.org/10.1007/s11199-005-3734-6

Kossek, E. E., Baltes, B. B., \& Matthews, R. A. (2011). How work-family research can finally have an impact in organizations. Industrial and Organizational Psychology, 4, 352-369. https://doi.org/10.1111/ j.1754-9434.2011.01353.x

Kutsyuruba, B., Godden, L., \& Bosica, J. (2019). The impact of mentoring on the Canadian early career teachers' well-being. International Journal of Mentoring and Coaching in Education, 8, 285-309. https://doi.org/10.1108/IJMCE-02-2019-0035

Laba, K., \& Geldenhuys, M. (2018). Positive interaction between work and home, and psychological availability on women's work engagement: a 'shortitudinal' study. South African Journal of Industrial Psychology, 44, 1-11. https://doi.org/10.4102/sajip. v44i0.1538

Le, T. T. B. T. (2015). Intellectual women and family. In T. V. T. Nguyen (Ed.), Intellectual women with national development (pp. 296-316). National University Press.

Lerato, M., \& Oladele, O. I. (2011). Job tenure as correlate of job satisfaction among North-West University Mafikeng campus employees. Journal of Social Sciences, 29, 63-71. https://doi.org/10.1080 /09718923.2011.11892956

Lundberg, U., \& Schaufeli, W. (2006). "Same same" but different? Can work engagement be discriminated from job involvement and organizational commitment? European Psychologist, 11, 119-127. https://doi.org/10.1027/1016-9040.11.2.119

Miao, Y., Li, L., \& Bian, Y. (2017). Gender differences in job quality and job satisfaction among doctors in rural western China. BMC Health Services Research, 17, 848. https://doi.org/10.1186/s12913-0172786-y
Middleton, N., Gunnell, D., Whitley, E., Dorling, D., \& Frankel, S. (2001). Secular trends in antidepressant prescribing in the UK, 1975-1998. Journal of Public Health, 23, 262-267. https://doi.org/10.1093/ pubmed/23.4.262

Nguyen, V. L. (2012). Subjective factors affecting the teaching motivation of university lecturers. Psychology Journal, 4, 76-88.

Nunnally, J. C., \& Bernstein, I. H. (2006). Psychometric theory (3rd ed.). Lightning Source.

Oldfield, G. R., \& Mostert, K. (2011). Work-home interaction of employees in the mining industry. South African Journal of Economic and Management Sciences, 12, 81-99. https://doi.org/10.4102/sajems. v12i 1.262

Page, K. M., \& Vella-Brodrick, D. A. (2009). The "what", "why" and "how" of employee well-being: a new model. Social Indicators Research, 90, 441-458. https://doi.org/10.1007/s11205-008-9270-3

Park, J. D., \& Gursoy, D. (2012). Generation effects on work engagement among U.S. hotel employees. International Journal of Hospitality Management, 31, 1195-1202. https://doi.org/10.1016/j.ijhm.2012. 02.007

Park, R., \& Searcy, D. (2012). Job autonomy as a predictor of mental well-being: The moderating role of quality-competitive environment. Journal of Business and Psychology, 27, 305-316. https://doi. org/10.1007/s10869-011-9244-3

Parker, S. K., Chmiel, N., \& Wall, T. D. (1997). Work characteristics and employee well-being within a context of strategic downsizing. Journal of Occupational Health Psychology, 2, 289-303. https://doi. org/10.1037/1076-8998.2.4.289

Paschoal, T., \& Tamayo, A. (2008). Construção e validação da escala de bem-estar no trabalho (Construction and validation of the work well-being scale). Avaliação Psicológica, 71, 11-22. https://doi. org/10.1590/S141565552012000200006

Paschoal, T., Torres, C., \& Porto, J. (2010). Felicidade no trabalho: Relações com suporte organizacional e suporte social (Happiness at work: Relations with organizational support and social support). Revista de Administração Contemporânea, 14, 1054-1072. https://doi.org/10.1590/S1415-65552010000700005

Praveen, P. J. (2018). Comparison of job satisfaction among managerial and non-managerial employees: a mathematical approach. International Journal of Pure and Applied Mathematics, 120, 1231-1255.

Ravenswood, K. (2017). Editorial: Gender \& wellbeing at work. New Zealand Journal of Employment Relations, 42, 1-6.

Rivera-Torres, P., Araque-Padilla, R. A., \& MonteroSimó, M. J. (2013). Job stress across gender: The importance of emotional and intellectual demands and social support in women. International Journal of Environmental Research and Public Health, 10, 375-389. https://doi.org/10.3390/ijerph10010375
The association between well-being at work and work-home interactions 
Bui Thi Hong Thai, Nguyen Thi Nhu Trang, Tran Thi Minh Duc
Rost, I., \& Mostert, K. (2007). The interaction between work and home of employees in the earthmoving equipment industry: Measurement and prevalence. South African Journal of Industrial Psychology, 33, 54-61. https://doi.org/10.4102/sajip.v33i2.377

Rothbard, N. (2001). Enriching or depleting? The dynamics of engagement in work and family roles. Administrative Science Quarterly, 46, 655-684. https://doi.org/10.2307/3094827

Rothmann, S., \& Baumann, C. (2014). Employee engagement: The effects of work-home/home-work interaction and psychological conditions. South African Journal of Economic and Management Sciences, 17, 515-530. https://doi.org/10.4102/sajems. v17i4.419

Ryff, C. D. (1989). Happiness is everything, or is it? Explorations on the meaning of psychological wellbeing. Journal of Personality and Social Psychology, 57, 1069-1081. https://doi.org/10.1037/00223514.57.6.1069

Ryff, C. D., \& Keyes, C. L. (1995). The structure of psychological well-being revisited. Journal of Personality and Social Psychology, 69, 719-727. https:// doi.org/10.1037//0022-3514.69.4.719

Schaufeli, W. B., Taris, T. W., \& Van Rhenen, W. (2008). Workaholism, burnout, and work engagement: Three of a kind or three different kinds of employee well-being? Applied Psychology, 57, 173-203. https://doi.org/10.1111/j.1464-0597.2007.00285.x

Sok, J., Blomme, R., \& Tromp, D. (2014). Positive and negative spillover from work to home: The role of organizational culture and supportive arrangements. British Journal of Management, 25, 456-472. https://doi.org/10.1111/1467-8551.12058

Stalcup, L. D., \& Pearson, T. A. (2001). A model of the causes of management turnover in hotels. Journal of Hospitality \& Tourism Research, 25, 17-30. https://doi.org/10.1177/109634800102500103

Taris, T. W., \& Schaufeli, W. B. (2015). Individual wellbeing and performance at work: a conceptual and theoretical overview. In $M$. van Veldhoven \& R. Peccei (Eds.), Well-being and performance at work: The role of context (pp. 15-34). Psychology Press.

Tomlinson, M. (2012). Graduate employability: a review of conceptual and empirical themes. Higher Education Policy, 25, 407-431. https://doi.org/10. 1057/hep.2011.26

Tran, T. T. T., Nguyen, N. B., Luong, M. A., Bui, T. H. A., Phan, T. D., Tran, V. O., Ngo, T. H., Minas, H., \& Nguyen, T. Q. (2019). Stress, anxiety and depression in clinical nurses in Vietnam: a crosssectional survey and cluster analysis. International Journal of Mental Health Systems, 13, 3. https://doi. org/10.1186/s13033-018-0257-4

Tran, X. B., Hoang, V. M., \& Nguyen, D. H. (2013). Factors associated with job satisfaction among commune health workers: Implications for human resource policies. Global Health Action, 6, 18619. https://doi.org/10.3402/gha.v6i0.18619

Van Aarde, A., \& Mostert, K. (2008). Work-home interaction of working females: What is the role of job and home characteristics? South African Journal of Industrial Psychology, 34, 1-10. https://doi. org/10.4102/sajip.v34i3.383

Van de Vijver, F., \& Hambleton, R. (1996). Translating tests: Some practical guidelines. European Psychologist, 1, 89-99. https://doi.org/10.1027/10169040.1.2.89

van Dierendonck, D., Haynes, C., Borrill, C., \& Stride, C. (2004). Leadership behavior and subordinate wellbeing. Journal of Occupational Health Psychology, 9, 165-175. https://doi.org/10.1037/1076-8998.9.2.165

Verweij, H., van Hooff, M. L. M., van der Heijden, F., Prins, J. T., Lagro-Janssen, A. L. M., van Ravesteijn, H., \& Speckens, A. E. M. (2017). The relationship between work and home characteristics and work engagement in medical residents. Perspectives on Medical Education, 6, 227-236. https:// doi.org/10.1007/s40037-017-0364-y

Warr, P. B. (1987). Work, unemployment, and mental health. Oxford University Press.

Wilks, D., \& Neto, F. (2013). Workplace well-being, gender and age: Examining the 'double jeopardy' effect. Social Indicators Research, 114, 875-890. https://doi.org/10.1007/s11205-012-0177-7

World Bank (2018). Vietnam's future jobs: Leveraging mega-trends for greater prosperity. Retrieved from https://www.worldbank.org/en/country/vietnam/ publication/vietnam-future-jobs-leveraging-megatrends-for-greater-prosperity 